\title{
Pengaruh Strategi Pelaksanaan Komunikasi Terapeutik Terhadap Kemampuan Berinteraksi Pada Pasien Isolasi Sosial Di RSJ Prof. Dr. Ildrem Medan TAHUN 2018
}

\author{
Murni Aritonang, S.Kep., Ns., MKM \\ Akademi Keperawatan Darmo \\ E-mail: murniaritonang93@yahoo.com
}

DOI : $10.33859 / \mathrm{dksm} . v 11 \mathrm{i} 1.576$

\begin{abstract}
ABSTRAK
Latar Belakang: Isolasi sosial adalah gangguan hubungan interpersonal yang terjadi akibat adanya kepribadian yang tidak fleksibel, sehingga menimbulkan perilaku maladaptif dan mengganggu fungsi seseorang dalam berhubungan. Komunikasi terapeutik dapat merubah dirinya menjadi seorang yang lebih terbuka dan dapat berinteraksi terhadap lingkungan. Ada empat tahapan dalam strategi komunikasi diberikan kepada pasien isolasi sosial.

Tujuan: untuk mengetahui pengaruh strategi pelaksanaan komunikasi terapeutik terhadap kemampuan berinteraksi pada pasien isolasi sosial di Rumah Sakit Jiwa Prof Dr.Ildrem Medan Tahun 2018.

Metode: penelitian ini menggunakan metode Quasi Experiment dengan rancangan penelitian Time Series Design. Dengan menggunakan teknik purposive sampling sebanyak 22 orang responden yang mempunyai masalah utama isolasi sosial berpartisipasi dalam penelitian ini. Teknik analisa yang digunakan adalah analisa univariat dan analisa bivariat dengan menggunakan uji t dependent

Hasil penelitian diperoleh bahwa ada pengaruh strategi pelaksanaan komunikasi terapeutik: Membina hubungan saling percaya terhadap kemampuan berinteraksi $(p=0,000)$; ada pengaruh strategi pelaksanaan komunikasi terapeutik: mengenal penyebab isolasi sosial terhadap kemampuan berinteraksi $(p=0,000)$; ada pengaruh strategi pelaksanaan komunikasi terapeutik: kemampuan pasien untuk menyebutkan keuntungan dan kerugian tidak berhubungan dengan orang lain terhadap kemampuan berinteraksi $(\mathrm{p}=0,000)$; ada pengaruh strategi pelaksanaan komunikasi terapeutik: kemampuan pasien untuk berinteraksi secara bertahap terhadap kemampuan berinteraksi $(\mathrm{p}=0,000)$. Simpulan: Berdasarkan hasil penelitian dapat disimpulkan bahwa ada Pengaruh Strategi Pelaksanaan Komunikasi Terapeutik Terhadap Kemampuan Berinteraksi Pada Pasien Isolasi Sosial di Rumah Sakit Jiwa Prof Dr.Ildrem. Untuk itu diharapkan sebaiknya strategi komunikasi terapeutik ini diterapkan pada setiap pasien isolasi sosial karena strategi komunikasi terapeutik merupakan salah satu tindakan keperawatan yang efektif.
\end{abstract}

Kata Kunci: Strategi Komunikasi Terapeutik, Kemampuan Berinteraksi, Pasien Isolasi Sosial 
Background: Social isolation is a disorder of interpersonal relationships that occurs as a result of an inflexible personality, which causes maladaptive behavior and disrupts one's function in relationships. Therapeutic communication can change him into a person who is more open and can interact with the environment. There are four stages in the communication strategy given to social isolation patients.

Objective: to determine the effect of therapeutic communication implementation strategies on the ability to interact in social isolation patients at the Prof. Dr. Illrem Mental Hospital, Medan, 2018. Methods: This study uses a Quasi Experiment method with a Time Series Design research design. By using purposive sampling technique as many as 22 respondents who have major problems with social isolation participated in this study. The analysis technique used is univariate analysis and bivariate analysis using the dependent t test

Result: The results showed that there is an effect of therapeutic communication implementation strategies: Fostering a trusting relationship on the ability to interact $(p=0.000)$; there is an effect of therapeutic communication implementation strategies: recognizing the causes of social isolation on the ability to interact $(p=0.000)$; there is an effect of therapeutic communication implementation strategy: the patient's ability to mention the advantages and disadvantages of not related to other people on the ability to interact $(p=0.000)$; There is an effect of therapeutic communication implementation strategy: the patient's ability to gradually interact with the ability to interact $(p=$ 0.000).

Conclusion: Based on the results of the study, it can be concluded that there is an effect of therapeutic communication implementation strategies on the ability to interact with patients with social isolation in Prof. Dr. Ildrem Mental Hospital. For this reason, it is hoped that this therapeutic communication strategy should be applied to every patient in social isolation because the therapeutic communication strategy is one of the most effective nursing actions.

Keywords: Therapeutic Communication Strategies, Interaction Ability, Patient Social Isolation

\section{Pendahuluan}

Isolasi sosial ini merupakan upaya menghindari komunikasi dengan orang lain karena merasa kehilangan hubungan akrab dan tidak mempunyai kesempatan untuk berbagi rasa, pikiran dan kegagalan. Klien mengalami kesulitan dalam berhubungan secara spontan dengan orang lain yang dimanifestasikan dengan mengisolasi diri, tidak ada perhatian dan tidak sanggup berbagi pengalaman (Yosef, 2015).

Karakteristik pasien yang mengalami gangguan dalam berhubungan dengan orang lain dapat dijumpai ketidaknyamanan dalam interaksi sosial, ketidak mampuan untuk menerima pendapat orang lain, gangguan interaksi dengan teman-teman dekat, keluarga, dan orang terdekat lainnya. Gangguan ini menyebabkan terjadinya perilaku manipulatif pada individu yakni perilaku agresif atau melawan (menentang) terhadap orang lain yang menghalangi keinginannya atau dalam usaha untuk memenuhi kebutuhannya.

Berdasarkan survei terhadap beberapa keluarga yang memiliki anggota keluarga yang menderita gangguan jiwa, diperoleh jumlah 
penderita yang mengalami gangguan jiwa pada tahun 2002 s/d 2015 sebanyak 1777 orang, halusinasi 925 orang $(49,89 \%)$, menarik diri 367 orang $(18,13 \%)$, waham 121 orang (3,56\%), harga diri rendah 234 orang $(15,10 \%)$, perilaku kekerasan 111 orang $(4,26 \%)$, defisit perawatan diri 19 orang (0,72\%). Pada tahun 2006 s/d 2016 sebanyak 2294 orang, halusinasi 1162 orang $(50,65 \%)$, menarik diri 462 orang (20,13\%), waham 130 orang $(5,66 \%)$, harga diri rendah 374 orang $(16,30 \%)$, perilaku kekerasan 128 orang (5,58\%), kerusakan komunikasi verbal 16 orang $(0,70 \%)$, defisit perawatan diri 21 orang $(0,91 \%)$, percobaan bunuh diri 1 orang (0,04\%) (Sudiyanti, dikutip dari Yosep, 2015).

Terkait dengan tingginya prevalensi masalah kesehatan jiwa saat ini, maka dibutuhkan pemberian komunikasi terapeutik yang tepat yang benar serta maksimal kepada masing-masing pasien yang mengalami Isolasi Sosial untuk menghadapi masalahnya dan meminimalkan resiko yang terjadi (Purba, Mahnum, Hardiah, 2015).

Komunikasi terapeutik ini merupakan salah satu bentuk terapi yang dilakukan secara individu oleh perawat kepada klien secara tatap muka perawat-klien dengan durasi waktu tertentu sesuai dengan tujuan yang ingin dicapai (Akemat, 2014).

Kemampuan menerapkan teknik komunikasi terapeutik memerlukan latihan dan kepekaan serta ketajaman perasaan karena komunikasi tidak terjadi dalam kemampuan, tetapi dalam dimensi nilai, waktu dan ruang yang turut mempengaruhi keberhasilan komunikasi yang terlihat melalui dampak terapeutiknya bagi pasien begitu juga bagi kepuasan perawat. Perawat harus memiliki tanggung jawab, moral yang tinggi dan didasari atas sikap peduli dan penuh kasih sayang serta perasaan ingin membantu orang lain (Widdyasih, 2016).

Adapun yang menjadi gambaran umum terhadap kemampuan berinteraksi pada pasien Isolasi sosial adalah pasien mampu berinteraksi secara bertahap dengan orang lain, menyadari perilaku isolasi sosialnya. Hal ini didukung oleh hasil penelitian Hartfielt 2014 yang menunjukkan bahwa sekitar $72 \%$ pasien gangguan jiwa yang mengalami isolasi sosial dan $64 \%$ orang yang tidak mampu memelihara diri sendiri.

Berdasarkan data yang diperolah dari RSJ Prof. DR. M. Ildrem Medan tahun 2015, diketahui jumlah pasien isolasi sosial tahun 2015 terdapat $19 \%$ atau 67 orang yang rawat inap. Data bulan Januari-September 2015 terdapat $20 \%$ atau 73 orang yang rawat inap (Laporan Medical Record Rumah Sakit Jiwa Daerah Provsu Medan ,2015).

Pada saat survei pendahuluan, peneliti mengamati perilaku-perilaku pasien yang mengalami Isolasi Sosial. Pasien tidak mampu bersosialisasi dengan pasien lain dalam satu bangsal. Mereka cenderung berdiam diri dan menjauh dari pasien lain bahkan ada beberapa orang yang selalu duduk di sudut kamar 
mereka. Pada saat interaksi pasien tidak mau memulai percakapan dengan peneliti. Pasien hanya menjawab dengan singkat bila ditanya.

Sejauh ini, strategi pelaksanaan komunikasi terapeutik pada pasien isolasi sosial hanya dilakukan oleh mahasiswa keperawatan yang sedang praktek dan menunjukkan hasil yang baik. Berdasarkan latar belakang, maka peneliti tertarik melakukan penelitian tentang Pengaruh Strategi Pelaksanaan Komunikasi Terapeutik terhadap Kemampuan Berinteraksi Pada Pasien Isolasi Sosial di RSJ Prof. DR. M. Ildrem Medan Tahun 2018.

\section{Metode Penelitian}

Jenis penelitian ini adalah penelitian Quasi Experiment yang menggunakan rancangan rangkaian waktu Time Series Design, yang digambarkan sebagai berikut (Setiadi, 2017)

Pre test Perlakuan Post test

\begin{tabular}{|lll|}
\hline P-1 & KT & P-2 \\
\hline
\end{tabular}

Keterangan: P-1 : Pre test 1

P-2 : Post test 2

KT : Diberikan SP

Data yang dikumpul dalam penelitian ini adalah data primer dan sekunder. Adapun data primer diperoleh dengan cara pengamatan langsung dan wawancara kepada calon responden dengan menggunakan lembar observasi yang sudah ada lalu mencukupkan data sekunder diperoleh dari pihak rekam medik Rumah Sakit Jiwa tersebut.
Hasil Penelitian

Tabel 1. Distribusi Frekuensi Karakteristik Pada Pasien Isolasi Sosial di RSJ Prof. dr. M. Ildrem Medan Utara Tahun 2018

\begin{tabular}{|c|c|c|c|c|}
\hline No & Karakteristik & Kategori & $\mathbf{n}$ & $\mathbf{\%}$ \\
\hline \multirow{2}{*}{1} & Umur & $<20$ Tahun & 0 & 0 \\
& (Tahun) & $21-35$ Tahun & 10 & 45,5 \\
& & $>35$ Tahun & 12 & 54,5 \\
\cline { 3 - 5 } & & Jumlah & $\mathbf{2 2}$ & $\mathbf{1 0 0}$ \\
\hline \multirow{2}{*}{} & \multirow{2}{*}{ Jenis } & Laki-Laki & 12 & 54,5 \\
& \multirow{2}{*}{ Kelamin } & Perempuan & 10 & 45,5 \\
\cline { 3 - 5 } & & Jumlah & $\mathbf{2 2}$ & $\mathbf{1 0 0}$ \\
\hline \multirow{3}{*}{} & \multirow{2}{*}{ Pendidikan } & SD & 3 & 13,6 \\
& & SLTP & 5 & 22,7 \\
& & SLTA & 14 & 63,6 \\
\cline { 3 - 5 } & & Jumlah & $\mathbf{2 2}$ & $\mathbf{1 0 0}$ \\
\cline { 3 - 5 } $\mathbf{4}$ & \multirow{2}{*}{ Agama } & Kristen & 9 & 40,9 \\
& & Islam & 11 & 50,0 \\
& & Budha & 2 & 9,1 \\
\cline { 3 - 5 } & & Jumlah & $\mathbf{2 2}$ & $\mathbf{1 0 0}$ \\
\hline
\end{tabular}

Berdasarkan tabel 1 dapat dilihat bahwa usia responden mayoritas $>35$ tahun yaitu $(54,5 \%)$, Jenis kelamin sebagian besar responden adalah laki-laki (54,5\%), pendidikan responden mayoritas adalah SLTA (63,3\%), serta sebagian besar responden beragama Islam $(50,0 \%)$.

\section{Analisa Univariat}

Dalam analisa univariat manggambarkan rata-rata kemampuan responden dalam melakukan dan mengikuti strategi pelaksanaan komunikasi terapeutik yang terdiri dari 4 strategi pertemuan.

Tabel 2. Distribusi Frekuensi Responden Strategi Pertemuan 1 Membina Hubungan Saling Percaya Pre test dan Post test di RSJ Prof. dr. M. Ildrem Medan Utara 2018

\begin{tabular}{|c|l|c|c|c|c|}
\hline \multirow{2}{*}{ No } & Membina & \multicolumn{2}{|c|}{ Pre test } & \multicolumn{2}{c|}{ Post test } \\
\cline { 3 - 6 } & Hubungan & & & & \\
& Saling Percaya & $\mathrm{n}$ & $\%$ & $\mathrm{n}$ & $\%$ \\
\hline 1 & Tidak Mampu & 15 & 68,2 & 1 & 4,5 \\
\hline 2 & Mampu & 7 & 31,8 & 21 & 95,5 \\
\hline & Total & $\mathbf{2 2}$ & $\mathbf{1 0 0}$ & $\mathbf{2 2}$ & $\mathbf{1 0 0}$ \\
\hline
\end{tabular}

Tabel 2 menunjukkan bahwa kemampuan pasien membina hubungan saling percaya pre test responden yang tidak mampu sebanyak 15 orang $(68,2 \%)$ dan responden yang mampu sebanyak 7 orang $(31,8 \%)$, sedangkan post test responden yang tidak mampu sebanyak 1 
orang $(4,5 \%)$ dan responden yang mampu sebanyak 21 orang $(95,5 \%)$.

Tabel 3 Distribusi Frekuensi Responden Strategi Pertemuan 2 Mengenal Penyebab Isolasi Sosial Pre Test dan Post Test di RSJ Prof. dr. M. Ildrem Medan Utara 2018

\begin{tabular}{|c|l|c|c|c|c|}
\hline \multirow{2}{*}{ No } & \multirow{2}{*}{\begin{tabular}{l} 
Mengenal \\
penyebab isolasi \\
\cline { 2 - 6 }
\end{tabular}} & $\mathrm{n}$ & $\%$ & $\mathrm{n}$ & $\%$ \\
\hline 1 & Tidak Mampu & 20 & 90,9 & 8 & 36,4 \\
\hline 2 & Mampu & 2 & 9,1 & 14 & 63,6 \\
\hline & Total & 22 & 100 & 22 & 100 \\
\hline
\end{tabular}

Tabel 3 menunjukkan bahwa kemampuan untuk mengenal penyebab isolasi sosial pre test responden yang tidak mampu sebanyak 20 orang $(90,9 \%)$ dan responden yang mampu sebanyak 2 orang $(9,1 \%)$, sedangkan post test responden yang tidak mampu sebanyak 8 orang $(36,4 \%)$ dan responden yang mampu sebanyak 14 orang $(63,6 \%)$.

Tabel 4.Distribusi Frekuensi Responden Strategi Pertemuan 3 Kemampuan Pasien Untuk Menyebutkan Keuntungan dan Kerugian Tidak Berhubungan dengan orang lain Pre Test dan Post Test di RSJ Daerah Provinsi Sumatera Utara 2018

\begin{tabular}{|c|l|c|c|c|c|}
\hline \multirow{2}{*}{ No } & Kemampuan pasien untuk menyebutkan & $\begin{array}{l}\text { keuntungan dan kerugian tidak berhubungan } \\
\text { dengan orang lain }\end{array}$ & \multicolumn{2}{|c|}{ Pre test } & \multicolumn{2}{|c|}{ Post test } \\
\cline { 3 - 6 } & $\mathrm{n}$ & $\%$ & $\mathrm{n}$ & $\%$ \\
\hline 1 & Tidak Mampu & 20 & 90,9 & 6 & 27,3 \\
\hline 2 & Mampu & 2 & 9,1 & 16 & 72,7 \\
\hline & Total & 22 & 100 & 22 & 100 \\
\hline
\end{tabular}

Tabel 4 di meunjukkan bahwa kemampuan pasien untuk menyebutkan keuntungan dak kerugian tidak berhubungan dengan orang lain pre test responden yang tidak mampu sebanyak 20 orang $(90,9 \%)$ dan responden yang mampu sebanyak 2 orang $(9,1 \%)$, sedangkan Post test responden yang tidak mampu sebanyak 6 orang $(27,3 \%)$ dan responden yang mampu sebanyak 16 orang $(72,7 \%)$.
Tabel 5 Distribusi Frekuensi Responden Strategi Pertemuan 4 Kemampuan pasien berinteraksi secara bertahap Pre Test dan Post Test di RSJ Daerah Provinsi Sumatera Utara 2018

\begin{tabular}{|c|l|c|c|c|c|}
\hline \multirow{2}{*}{ No } & \multirow{2}{*}{ Patuh Minum Obat } & \multicolumn{2}{|c|}{ Pre test } & \multicolumn{2}{|c|}{ Post test } \\
\cline { 3 - 6 } & & $\mathrm{n}$ & $\%$ & $\mathrm{n}$ & $\%$ \\
\hline 1 & Tidak Mampu & 20 & 90,9 & 1 & 4,5 \\
\hline 2 & Mampu & 2 & 9,1 & 21 & 95,5 \\
\hline & Total & 22 & 100 & 22 & 100 \\
\hline
\end{tabular}

Berdasarkan tabel 5 dapat dilihat bahwa kemampuan pasien berinteraksi secara bertahap pre test responden yang tidak mampu sebanyak 20 orang $(90,9 \%)$ dan responden yang mampu sebanyak 2 orang $(9,1 \%)$, sedangkan post test responden yang tidak mampu sebanyak 1 orang $(4,5 \%)$ dan responden yang mampu sebanyak 21 orang (95,5\%). yang mampu mereka masih mau menerima dan melaksanakan yang diberikan oleh sipeneliti.

Tabel 6. Pengaruh Strategi Pelaksanaan Komunikasi Terapeutik Terhadap Kemampuan Berinteraksi Pada Pasien Isolasi Sosial Pre Test dan Post Test di RSJ Prof. dr. M. Ildrem Medan Utara 2018

\begin{tabular}{|c|c|c|c|c|c|c|}
\hline \multirow[t]{2}{*}{ No } & \multirow{2}{*}{$\begin{array}{l}\text { Kemampuan } \\
\text { Pasien } \\
\text { Berinteraksi }\end{array}$} & \multicolumn{2}{|c|}{ Mean } & \multicolumn{2}{|c|}{ SD } & \multirow[b]{2}{*}{$\mathrm{p}$} \\
\hline & & $\begin{array}{l}\text { Pre } \\
\text { test }\end{array}$ & $\begin{array}{c}\text { Post } \\
\text { test }\end{array}$ & $\begin{array}{l}\text { Pre } \\
\text { test }\end{array}$ & $\begin{array}{c}\text { Post } \\
\text { test }\end{array}$ & \\
\hline 1 & $\begin{array}{c}\text { Membina } \\
\text { Hubungan } \\
\text { Saling Peracaya }\end{array}$ & 1,32 & 1,95 & $\begin{array}{c}0,47 \\
7\end{array}$ & $\begin{array}{c}0,21 \\
3\end{array}$ & $\begin{array}{c}0,0 \\
00\end{array}$ \\
\hline 2 & $\begin{array}{c}\text { Mengenal } \\
\text { penyebab } \\
\text { isolasi sosial }\end{array}$ & 1,09 & 1,64 & $\begin{array}{c}0,29 \\
4\end{array}$ & $\begin{array}{c}0,49 \\
2\end{array}$ & $\begin{array}{c}0,0 \\
00\end{array}$ \\
\hline 3 & $\begin{array}{l}\text { Kemampuan } \\
\text { pasien } \\
\text { menyebutkan } \\
\text { keuntungan dan } \\
\text { kerugian tidak } \\
\text { berhubungan } \\
\text { dengan orang } \\
\text { lain }\end{array}$ & 1,09 & 1,73 & $\begin{array}{c}0,29 \\
4\end{array}$ & $\begin{array}{c}0,45 \\
6\end{array}$ & $\begin{array}{c}0,0 \\
00\end{array}$ \\
\hline 4 & $\begin{array}{l}\text { Kemampuan } \\
\text { pasien } \\
\text { berinteraksi } \\
\text { secara bertahap }\end{array}$ & 1,09 & 1,95 & $\begin{array}{c}0,29 \\
4\end{array}$ & $\begin{array}{c}0,21 \\
3\end{array}$ & $\begin{array}{c}0,0 \\
00\end{array}$ \\
\hline
\end{tabular}

Berdasarkan table 6 dengan menggunakan $U j i$

$t$ Dependent ada perbedaan rata-rata kemampuan berinteraksi sebelum dan setelah 
Dinamika Kesehatan Jurnal Kebidanan dan Keperawatan Vol 11 No. 1 Juli 2020 ( ISSN: 2086-3454 EISSN: 2549-4058) url: http://ojs.dinamikakesehatan.unism.ac.id DOI : https://doi.org/10.33859/dksm.v11i1

Hubungan Antara Perilaku Caring Perawat Dengan Tingkat Kecemasan Keluarga (Primary Caregiver) Yang Anggota Keluarganya Dirawat Di Instalasi Gawat Darurat

dilakukannya strategi komunikasi terapeutik pada pasien isolasi sosial dengan $(\mathrm{p}=0,000)$, dimana Strategi Pelaksanaan Komunikasi Terapeutik: Membina Hubungan Saling Percaya Pre Test nilai mean $=1,32, \mathrm{SD}=0,477$; sedangkan Post Test mean $=1,95, \mathrm{SD}=0,045$ dengan $\mathrm{p}=0,000$. Pada Strategi Pelaksanaan Komunikasi Terapeutik: Mengenal penyebab isolasi sosial Pre Test nilai mean =1,09, $\mathrm{SD}=0,294$; sedangkan post test nilai mean $=1,64, \mathrm{SD}=0,492$ dengan $\mathrm{p}=0,000$. Pada Strategi Pelaksanaan Komunikasi Terapeutik: Kemampuan pasien menyebutkan keuntungan dan kerugian tidak berhubungan dengan orang lain Pre Test nilai mean= 1,09, SD=0,294; sedangkan post test nilai mean=1,73, $\mathrm{SD}=0,456$ dengan $\mathrm{p}=0,000$. Pada Strategi Pelaksanaan Komunikasi Terapeutik: Kemampuan pasien berinteraksi secara bertahap Pre Test nilai mean=1,09, SD=0,294; sedangkan Post Test nilai mean=1,95, $\mathrm{SD}=0,213$ dengan $\mathrm{p}=0,000$. Ini berarti hipotesa diterima yaitu terdapat pengaruh strategi pelaksanaan komunikasi terhadap kemampuan berinteraksi pada pasien isolasi sosial.

Tabel 7. Distribusi Pengaruh Strategi Pelaksanaan Komunikasi Terapeutik Terhadap Kemampuan Berinteraksi Pada Pasien Isolasi Sosial Pre Test dan Post Test (Seluruh SP) di RSJ Prof. dr. M. Ildrem Medan Utara 2018

\begin{tabular}{|l|l|l|l|l|c|c|}
\hline No & Kemampuan & Mean & SD & \multicolumn{2}{|c|}{ Perbedaan } & P \\
\cline { 4 - 6 } & $\begin{array}{l}\text { Pasien } \\
\text { Berinteraksi }\end{array}$ & & & $\begin{array}{l}\text { Mea } \\
\mathrm{n}\end{array}$ & SD & \\
\hline 1 & Pre Test & 1,00 & 0,000 & & & \\
\hline 2 & Post Test & 1,95 & 0,213 & $\begin{array}{c}0,95 \\
5\end{array}$ & $\begin{array}{c}0,21 \\
3\end{array}$ & $\begin{array}{l}0,0 \\
00\end{array}$ \\
\hline
\end{tabular}

Berdasarkan tabel 7 terlihat bahwa berdasarkan uji statistic dengan menggunakan Uji t Dependent ada perbedaan mean Pengaruh Strategi Pelaksanaan Komunikasi Terapeutik Terhadap Kemampuan Berinteraksi Pada Pasien Isolasi Sosial di Rumah Sakit Jiwa Daerah Provsu Tahun 2018 mempunyai nilai mean Pre Test 1,00 dan Post test 1,95 dengan $(\mathrm{p}=0,000)$ dan Standart Deviasi $\pm 0,213$. Dimana perbedaan mean kemampuan berinteraksi setelah dilakukan komunikasi terapeutik yaitu 0,955 .

\section{Pembahasan}

Strategi Pertemuan 1: Membina Hubungan Saling Percaya

Hasil analisa bivariat menunjukkan bahwa pada strategi pertemuan 1 pre test, bahwa responden yang tidak mampu sebanyak 15 orang $(68,2 \%)$ dan responden yang mampu sebanyak 7 orang $(31,8 \%)$, dan pada strategi pertemuan 1 Post test, bahwa responden yang tidak mampu sebanyak 1 orang $(4,5 \%)$ dan responden yang mampu sebanyak 21 orang $(95,5 \%)$.

Hasil penelitian menunjukkan bahwa 1 responden tidak mampu setelah dilaksanakan strategi komunikasi terapeutik hal ini terkait karena si pasien merasa bahwa dirinya memang sudah tidak berharga lagi di mata orang yang ada disekitarnya dan pasien juga mengalami halusinasi penglihatan, sedangkan pada pasien yang mampu hubungan saling percaya antara perawat dan pasien sudah terbina, mereka sudah dapat mengenal suster 
Dinamika Kesehatan Jurnal Kebidanan dan Keperawatan Vol 11 No. 1 Juli 2020 ( ISSN: 2086-3454 EISSN: 2549-4058) url: http://ojs.dinamikakesehatan.unism.ac.id DOI : https://doi.org/10.33859/dksm.v11i1

Hubungan Antara Perilaku Caring Perawat Dengan Tingkat Kecemasan Keluarga (Primary Caregiver) Yang Anggota Keluarganya Dirawat Di Instalasi Gawat Darurat

yang mengajak berbicara dan sudah memiliki kontak mata yang baik.

Berdasarkan uji normalitas yaitu menggunakan uji t Dependent pada strategi pertemuan 1 menunjukkan bahwa ada pengaruh strategi pelaksanaan komunikasi terapeutik: membina hubungan saling percaya terhadap kemampuan berinteraksi pada pasien isolasi sosial di Rumah Sakit Jiwa Daerah Provinsi Sumatera Utara tahun 2018. Ditunjukkan dengan nilai P (Asymp Sig (2Tailed) < 0,05. Strategi pelaksanaan komunikasi terapeutik terhadap kemampuan berinteraksi pada pasien isolasi sosial yang telah dilaksanakan di RSJ Prof. DR. M. Ildrem Medan sangat berpengaruh, hal ini sesuai dengan penelitian yang dilakukan Ilham (2016) yang menyatakan adanya pengaruh strategi pelaksanaan komunikasi terapeutik terhadap kemampuan berinteraksi pada pasien isolasi sosial di rumah sakit jiwa Dr. Soeparto Hardjohoesodo Kendari.

\section{Strategi Pertemuan 2: Mengenal Penyebab Isolasi Sosial}

Pada strategi pertemuan 2 pre test, responden yang tidak mampu sebanyak 20 orang $(90,9 \%)$ dan responden yang mampu sebanyak 2 orang $(9,1 \%)$, dan pada strategi pertemuan 2 post test, responden yang tidak mampu sebanyak 8 orang $(36,4 \%)$ dan responden yang mampu sebanyak 14 orang $(63,6 \%)$. Pada strategi pertemuan 2, terdapat 8 responden tidak mampu setelah dilaksanakan strategi komunikasi terapeutik hal ini terkait karena mereka sibuk dengan kegiatan sendiri dan tidak mau berhubungan dengan orang yang ada disekitarnya, pasien yang lain yaitu 14 orang sudah mampu menyebutkan penyebab isolasi sosialnya dan menyebutkan orang terdekat dengannya. Hasil uji $t$ Dependent menunjukkan bahwa ada pengaruh strategi pelaksanaan komunikasi terapeutik: mengenal penyebab isolasi sosial terhadap kemampuan berinteraksi pada pasien isolasi sosial di Rumah Sakit Jiwa Daerah Provinsi Sumatera Utara Medan tahun 2018. Ditunjukkan dengan nilai P (Asymp Sig (2Tailed $)<0,05$. Berdasarkan hasil penelitian yang telah dilaksanakan peneliti, dapat dilihat Adanya pengaruh strategi pelaksanaan komunikasi terapeutik terhadap kemampuan berinteraksi pada pasien isolasi sosial. Hal ini sesuai dengan pendapat Purba (2015) kesejahteraan manusia berorientasi secara sosial, dan untuk meningkatkan kepuasan hidup, individu harus mampu menciptakan hubungan interpersonal yang sehat/positif. Hubungan interpersonal dikatakan sehat apabila individu dapat terlibat dalam suatu hubungan yang intim dengan orang lain, sementara ia tetap dapat mempertahankan identitasnya. 
Dinamika Kesehatan Jurnal Kebidanan dan Keperawatan Vol 11 No. 1 Juli 2020 ( ISSN: 2086-3454 EISSN: 2549-4058) url: http://ojs.dinamikakesehatan.unism.ac.id DOI : https://doi.org/10.33859/dksm.v11i1

Hubungan Antara Perilaku Caring Perawat Dengan Tingkat Kecemasan Keluarga (Primary Caregiver) Yang Anggota Keluarganya Dirawat Di Instalasi Gawat Darurat

Staregi Pertemuan 3: Kemampuan Pasien Menyebutkan Keuntungan dan Kerugian Tidak Berhubungan Dengan Orang Lain.

Pada strategi pertemuan 3 pre test, responden yang tidak mampu sebanyak 20 orang $(90,9 \%)$ dan responden yang mampu sebanyak 2 orang $(9,1 \%)$, dan pada strategi pertemuan 3 post test, responden yang tidak mampu sebanyak 6 orang $(27,3 \%)$ dan responden yang mampu sebanyak 16 orang $(72,7 \%)$. Pada strategi pertemuan 3, terdapat 6 responden tidak mampu setelah dilaksanakan strategi komunikasi terapeutik hal ini terkait karena mereka sibuk dengan kegiatan sendiri dan mereka merasa sudah mengenal orang yang disekitarnya, bagi responden yang mampu yaitu 16 orang mereka sudah mampu menyebutkan kegiatan yang sudah diajarkan, mampu menyebutkan keuntungan kalau tidak berhubungan dengan orang lain dan kerugian bila tidak berhubungan dengan orang lain. Hasil uji t Dependent menunjukkan bahwa ada pengaruh strategi pelaksanaan komunikasi terapeutik: kemampuan pasien menyebutkan keuntungan dan kerugian tidak berhubungan dengan orang lain terhadap kemampuan berinteraksi pada pasien isolasi sosial di Rumah Sakit Jiwa Daerah Provinsi Sumatera Utara Medan tahun 2018. Ditunjukkan dengan nilai P (Asymp Sig (2-Tailed) $<0,05$.
Strategi Pertemuan 4: Kemampuan Pasien Berinteraksi Secara Bertahap

Pada strategi pertemuan 4 pre test, responden yang tidak mampu sebanyak 20 orang $(91,9 \%)$ dan responden yang mampu sebanyak 2 orang $(9,1 \%)$, dan pada strategi pertemuan 4 post test, responden yang tidak mampu sebanyak 1 orang $(4,5 \%)$ dan responden yang mampu sebanyak 21 orang (95,5\%). Hasil uji t Dependent menunjukkan bahwa ada pengaruh strategi pelaksanaan komunikasi terapeutik: kemampuan pasien berinteraksi secara bertahap terhadap kemampuan berinteraksi pada pasien isolasi sosial di Rumah Sakit Jiwa Daerah Provinsi Sumatera Utara tahun 2018. Ditunjukkan dengan nilai P (Asymp Sig (2-Tailed) < 0,05. Pada strategi pertemuan 4 , terdapat 1 responden tidak mampu setelah dilaksanakan strategi komunikasi terapeutik hal ini terkait karena ia takut dengan orang yang disekitarnya, karena pengalaman masa lalu yang membuatnya jauh dari orang lain seperti dimarahi dan direndahkan oleh keluarganya sedangkan pasien yang mampu 21 orang sudah mengetahui cara berinteraksi klien-perawat, klien-perawat-perawat lain, klien-perawat lain-klien lain, klien-keluarga. 
Dinamika Kesehatan Jurnal Kebidanan dan Keperawatan Vol 11 No. 1 Juli 2020 ( ISSN: 2086-3454 EISSN: 2549-4058) url: http://ojs.dinamikakesehatan.unism.ac.id DOI : https://doi.org/10.33859/dksm.v11i1

Hubungan Antara Perilaku Caring Perawat Dengan Tingkat Kecemasan Keluarga (Primary Caregiver) Yang Anggota Keluarganya Dirawat Di Instalasi Gawat Darurat

\section{Pengaruh Strategi Pelaksanaan Komunikasi Terapeutik Terhadap Kemampuan Berinteraksi}

Pada penggabungan semua strategi pertemuan terlihat bahwa berdasarkan uji statistic dengan menggunakan Uji t Dependen ada perbedaan rata-rata Pengaruh Strategi Pelaksanaan Komunikasi Terapeutik Terhadap Kemampuan Berinteraksi Pada Pasien Isolasi Sosial di Rumah Sakit Jiwa Daerah Provsu Tahun 2018, mempunyai nilai Pre Test mean=1,00 dan Post test mean=1,95 dengan $(\mathrm{p}=0,000)$ dan Standart Deviasi $\pm 0,213$. Dimana perbedaan rata-rata kemampuan berinteraksi setelah dilakukan komunikasi terapeutik yaitu 0,955 . Ini berarti hipotesa diterima yaitu terdapat pengaruh strategi pelaksanaan komunikasi terapeutik terhadap kemampuan berinteraksi.

Komunikasi memegang peranan penting karena untuk mendapatkan data subyektif dari pasien dibutuhkan kemampuan berkomunikasi yang efektif. Perawat yang menguasai teknik ini akan lebih efektif dalam mencapai tujuan telah ditetapkan. Hal ini terjadi karena dengan memiliki keterampilan berkomunikasi terapeutik perawat akan lebih muda menjalin hubungan saling percaya dengan klien. Dampak selanjutnya adalah memberikan kepuasan secara professional dalam pelayanan keperawatan dan akan meningkatkan citra profesi serta rumah sakit.

Penelitian Cendikia (2015), dari pembahasan dapat disimpulkan bahwa hampir seluruh responden mengatakan komunikasi terapeutik perawat pada fase kerja baik dan sebagian besar responden mengatakan cukup puas terhadap komunikasi terapeutik perawat pada fase kerja. Maka komunikasi terapeutik perawat yang dinilai baik oleh hampir seluruh responden perlu diperhatikan sebagai modal dasar dalam memberikan pelayanan kepada pasien dan masyarakat. Kepuasan pasien terhadap komunikasi terapeutik perawat pada fase kerja yang sebagian besar responden mengatakan cukup dapat ditingkatkan dengan perbaikan sistem pelayanan yang lain, misalnya dengan peningkatan sarana dan fasilitas yang diterima pasien.

Berdasarkan hasil uji analisa Spearmen'n correlation pada penelitian Salman (2015) menunjukkan $\mathrm{r}=0,004$ dimana $\mathrm{p}=0,972$ yang berarti tidak terdapat pengaruh yang signifikan antara komunikasi terapeutik perawat dengan kepuasan pasien.

Berdasarkan penelitian Harmini (2016), menunjukkan bahwa penerapan komunikasi terapeutik perawat baik dengan nilai $86,5 \%$ (76\%-100\%). Dapat disimpulkan terdapat hubungan antara penerapan komunikasi terapeutik dengan kepuasan mutu pelayanan perawatan.

Komunikasi terapeutik termasuk komunikasi interpersonal dengan titik tolak saling memberikan pengertian antar perawat dengan pasien. Persoalan mendasar dan komunikasi adalah adanya saling membutuhkan antara perawat dan pasien, sehingga dapat dikategorikan ke dalam 
Dinamika Kesehatan Jurnal Kebidanan dan Keperawatan Vol 11 No. 1 Juli 2020 ( ISSN: 2086-3454 EISSN: 2549-4058) url: http://ojs.dinamikakesehatan.unism.ac.id DOI : https://doi.org/10.33859/dksm.v11i1

Hubungan Antara Perilaku Caring Perawat Dengan Tingkat Kecemasan Keluarga (Primary Caregiver) Yang Anggota Keluarganya Dirawat Di Instalasi Gawat Darurat

komunikasi pribadi di antara perawat dan pasien, perawat membantu dan pasien menerima bantuan (Indrawati, 2013).

\section{Saran}

\section{Bagi Pasien Isolasi}

Melaksanakan apa yang diajarkan oleh petugas dan melaksanakannya sesering mungkin untuk meningkatkan kesehatan, khususnya untuk meningkatkan kemampuan pasien dalam berinterkasi dengan orang lain terutama dengan orang- orang yang disekitarnya.

\section{Bagi Rumah Sakit Jiwa}

Bagi perawat yang bertugas di rumah sakit jiwa agar meningkatkan pelayanan pada pasien isolasi sosial dengan melaksanakan strategi pelaksanaan komunikasi terapeutik yang membantu klien mempermudah proses penyembuhan bagi pasien baru maupun pasien lama sehingga mampu dalam berinteraksi dengan orang lain.

\section{Bagi Penelitian Keperawatan}

Penelitian ini dapat digunakan sebagai informasi tambahan untuk penelitian selanjutnya. Sebaiknya pemilihan sampel lebih selektif, dan waktunya diperpanjang.

\section{Keterbatasan Peneliti}

Kendala yang dimiliki oleh sipeneliti yaitu sulit membina hubungan saling percaya, ada pasien yang mau melaksanakan yang diajarkan dan ada yang mengabaikannya. peneliti juga melaksanakan kegiatan di ruangan tempat sipeneliti dinas seperti mengepel ruangan, memberikan obat, mendampingi pasien makan dan menyuci piring.

\section{DAFTAR PUSTAKA}

Alimul, Aziz. (2016). Metode Penelitian Keperawatan dan Teknik Analisa Data. Jakarta: Salemba Medika.

Carman, Linda. (2017). Kesehatan Jiwa dan Psikiatri Pedoman Klinis Perawat. Edisi 2. Jakarta: EGC.

Dalami, Ermawati. (2015). Konsep Dasar Keperawatan Kesehatan Jiwa. Jakarta: CV Trans Info Media.

Edison, J.P. (2015). Pengaruh Intervensi Rehabilitasi Terhadap

Ketidakmampuan Bersosialisasi pada Penderita Skizofrenia yang Dirawat di Rumah Sakit Jiwa Daerah Provsu Medan. Tesis (Pasca Sarjana USU).

Erlinafsiah. (2015). Model Perawat dalam Praktek Keperawatan Jiwa. Jakarta: Trans

Info Media.

Keliat, B.A., dan Akemat. (2015). Model Praktik Keperawatan Profesional Jiwa. Jakarta: EGC.

Keliat, B.A., Ria, dan dkk. (2006). Proses Keperawatan Kesehatan Jiwa. Edisi 2.

Jakarta: EGC

Kusumawati, F., dan Hartono. (2015). Buku Ajar Keperawatan Jiwa. Jakarta: Salemba Medika.

Mistofa, Bisri. Komunikasi Terapeutik Pada Klien Gangguan Jiwa. 13 juli 2015. Artikel FIK UNPADJ. 
Notoadmojo, Soekidjo. (2017). Metodologi Penelitian Kesehatan. Edisi 3. Jakarta: PT Rineka Cipta.

Purba, J.M., dan Wahyuni. (2015). Asuhan Keperawatan pada Klien dengan Masalah Psikososial dan Gangguan Jiwa. Medan: USU Press.

Setiadi. (2017). Konsep dan Penulisan Riset Keperawatan. Yogyakarta: Graha Ilmu.

Safaria, T. (2015). Terapi dan Konseling Gestalt. Edisi 1. Yogyakarta: Graha Ilmu.

Stuart, G.W. (2017). Buku Saku Keperawatan Jiwa. Edisi 5. Jakarta: EGC.

Yosep, Iyus. (2015). Keperawatan Jiwa. Edisi Revisi. Jakarta: PT Refika Aditama.

Wahyu, Purwaningsih. (2015). Asuhan Keperawatan Jiwa Dilengkapi Terapi Modalitas dan Standard Operating Procedure (SOP). Jogjakarta: Mitra Cendekia.

Wasis. (2016). Pedoman Riset Praktis untuk Profesi Perawat. Cetakan I. Jakarta: EGC.

Widdyasih. 2016. Penderita Gangguan Jiwa. Diakses 07 Februari 2015, http:/wordpress.com 